\title{
Battening down the hatches
}

\section{As the fallout from 'Climategate' rumbles on, the scientific community needs to stick to what it is best at: the gathering, interpretation and dissemination of accurate data.}

S ince the recent events of 'Climategate', when thousands of emails were hacked at the Climatic Research Unit of the University of East Anglia (UK), it has seemed as if science is under siege. Any cursory stroll through the Internet shows just how inflamed this issue has become, and it now seems the tone of the debate has reached an all-time low. Climate scientists have been accused by skeptics of pulling rank, malfeasance, obfuscation and even the flagrant fabrication of data. What is more, it seems that the 'revelations' of Climategate have sometimes been misappropriated by certain people intent on 'knocking' science more generally. At times, scientists have responded in kind by accusing climate-change skeptics of 'voodoo science' and even a form of 'Holocaust denial'. At one level it is understandable how the relentless criticism and abuse of Freedom of Information requests for scientists to reveal the minutiae of their data has resulted in such intemperate responses. However, this kind of response may well play into the hands of skeptics who will then simply spin it as further evidence of the arrogant nature of scientists.

So what is the best way for scientists to respond to such critics? One approach advocated by the UK Government's Chief Scientific Adviser John Beddington is for scientists to be as transparent as possible with their data and to clearly highlight any uncertainties. This is a patently sensible approach and one advisable for any potentially divisive area of science, whether climate change, stem cells or vaccination. Many scientists do go to great pains to point out potential caveats in their work, and indeed in the case of the climatologists, they stress that their long-term predictions are based on models, albeit sophisticated ones. Unfortunately, politicians who operate over shorter time frames and prefer to deal in more clear-cut scenarios often require science advisors to come up with fairly unambiguous recommendations. This is an unenviable task for any scientific discipline, and such pressure may be a special issue for climatologists, whose area of research has become so politicized (for example, http://dvsun3.gkss.de/BERICHTE/GKSS_Berichte_2007/ GKSS_2007_11.pdf). Policy makers need to remain mindful of this. Another important approach is effective engagement with the public in the science of this debate. Already there have been very laudable attempts in this context, such as the authoritative and readable RealClimate website and the response of the UK National Health Service to the recent measles-mumps-rubella vaccine controversy. These are both excellent initiatives and should be wholeheartedly welcomed.

Of course, there will always be intractable skeptics who will remain unconvinced come what may; to them, anthropogenic climate change is much like the Apollo moon landings: a grand conspiracy cooked up for political ends. However, the vast majority of skeptics are wellmeaning and concerned people who remain undecided about the science of climate change or are simply concerned about the latest health scare. These 'swing voters' are the people scientists need to reach out to. It is telling that most of the criticism of established climate science and/ or scientists in general is confined to the blogosphere or is conducted by interested amateurs, yet these views have sometimes proven incredibly persuasive. Clearly, it is worrisome when the general public is swayed not by a large and cohesive group of experts but by lobbyists or individual people who often lack any relevant expertise. The Internet abounds with insidious misinformation about the supposed dangers of fluoridation, vaccination or any number of other medical issues. The perplexing appeal of some of these opinions might be explained in part as a knee-jerk reaction of the public to the sporadic exhortations of certain governments, officials and even some scientists. The image of a plucky maverick (such as a climate-change skeptic or measlesmumps-rubella vaccine skeptic) who is finally proven right after struggling against the overwhelming scientific consensus is a seductive but almost wholly inaccurate one. Yes, vindicated mavericks do exist, but they also tend to be the exception.

Another problem may lie in part at the door of the scientific community itself. The contentious nature of climate change has, at least in the eyes of some of the public, led scientists to play fast and loose with the rules of how science is carried out. For example, there have been assertions that certain climate scientists colluded against an academic journal because it published a research paper at variance with anthropogenic global warming. That accusation remains unproven, but if true, it would be gravely damaging to the credibility of science and should be condemned as unacceptable in no uncertain terms. More so now than ever, the popular press is awash with articles about ivory towers and bias in peer review. Therefore, the last thing the scientific community needs to do is to douse this fire with additional accelerant. Indeed, there can be quite a bit of misunderstanding by the public about how peer review operates, so clarifying this would surely be helpful. Finally, a recent op-ed article in The Guardian, a UK broadsheet, declared that Climategate had finally knocked scientists in general off their pedestals and exposed them as "human after all," no different from bankers, lawyers or, horror of horrors, journalists. This should not be news to anyone, least of all practicing scientists who are only too aware of the politics of research and the occasional vagaries of peer review. Yes, science occasionally suffers setbacks, but it remains the surest way of getting to the truth, and it is of this that the doubting public needs to be assured. 